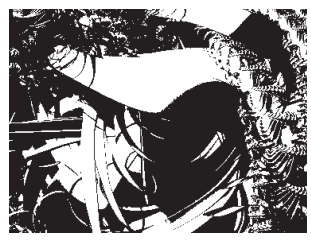

doi:10.5559/di.20.2.03

\title{
THE APPLICATION OF MULTIPLE CRITERIA ASSESSMENT OF PRODUCTION SECTORS ON INCREASING QUALITY OF LIFE
}

Renata SLABE ERKER, Vlado LAVRAČ

Institute for Economic Research, Ljubljana

UDK: 330.59(497.4):17.023.34

$316.728(497.4)$

Izvorni znanstveni rad

Primlieno: 24. 6. 2009.

The piffalls of distorted consumption patterns are increasingly clear in modern society. They are seen in the vicious circle of rushed work, earning and spending, which does not generally provide people with greater life satisfaction. As much research has indicated, a 'happiness paradox' occurs. In developed countries, at least, people are not becoming happier, although their material wealth or living standard has continually increased over time. This indicates that other non-material elements of well-being are at least as important as material elements for satisfaction with life. This suggests that a paradigm for social development must be directed away from increasing one-sided economic development at any cost towards sustainable development, if not to maximising the overall happiness in a society. This paper brings an innovative attempt to provide some guidance as to the question which changes in the production structure, beside changes in consumption pattern, could contribute more to higher quality of life. It uses an established method - multi-criteria decision analysis (MCDA) - to combine academic theoretical and empirical work on happiness with the policy goal of increasing quality of life and promoting sustainable development. The use of multiple criteria assessment ranks production sectors on the basis of their contribution to the individual and overall quality of life criteria. The paper addresses the case of Slovenia, though the method is equally applicable in principle to other countries.

Keywords: life satisfaction, quality of life, production sectors, ranking, multiple criteria decision analysis 
Although quality of life has, until recently, been primarily of interest to sociologists, in the past decade it has increasingly gained the attention of economists. The crisis now being experienced in all areas of development - economic, environmental and social - has led to traditional one-sided valuations of development losing their advocates. It is clear that an increase in GDP does not necessarily mean a higher quality of life. Life satisfaction in the developed world has not changed over the past 50 years, despite the fact that the purchasing power more then doubled, measured by real income per capita (Layard, 2006). Rapid economic growth has increased material well-being, but hardly also quality of life, since it causes negative external effects such as impairing environmental and social capital, including interpersonal relations. Experts speak of a 'happiness paradox', which is usually explained by means of valuing consumption and satisfaction in relative terms. This depends on the material standard of the social environment in which an individual lives and works, changes in their aspirations and their adaptation to another, higher standard of living (Frank, 1999). This means that existing patterns of consumption and chronic time pressure are an expression of individuals' assessment of their relative situation.

An alternative explanation of the happiness paradox is offered by the 'growth as substitution process' or GASP models (Bartolini, 2007). GASP theory is based on the conviction that well-being is largely based on goods that are not purchased on the market, but are freely available in the natural and social environment, such as clear air, water, unspoilt nature, and quality interpersonal relationships. These goods are reduced by a process of rapid and one-sided economic growth due to its negative externalities, which reduce well-being. In order to maintain their level of well-being unchanged, they must replace the increasingly rare, freely available goods with marketable, manufactured consumer goods. This leads to a process of substitution of free goods with market goods within the process of economic growth. Social and environmental degradation, as a negative externality of economic growth, becomes the driving force for continued economic growth, since the market must produce and offer manufactured products to substitute the disappearing free goods. This leads to a vicious circle of economic growth leading to environmental and social degradation, which leads to continued economic growth and continued environmental and social degradation, and so on. Economic growth is not therefore the consequence of irrational conduct, but a failure of co-ordination, in the sense of a conflict between individual and common objectives due to a failure to consider the effect of externalities. A failure of 
DRUŠ. ISTRAŽ. ZAGREB GOD. 20 (2011), BR. $2(112)$

STR. $337-357$

SLABE ERKER, R., LAVRAČ, V.: THE APPLICATION OF. co-ordination is not the result of human nature, but of the institutional system i.e. the functioning of the market mechanism, which does not provide correct signals of people's needs. Values such as time, love, tolerance, understanding and cooperation are not produced by the market mechanism and therefore no one directly propagates them.

The possibility of improving the current co-ordination mechanism, the consequences of which are market failures, including the distortion of consumption in society, are in the short term primarily top-down, entailing redefinition of the state's regulatory role, and in the long term also bottom-up, by educating first individuals and then society as a whole through a range of channels such as upbringing, education, and the media, which are available as the means of changing moral patterns and re-evaluating social values. It is primarily in this way that one can envisage the possibility of gradually establishing a paradigm of sustainable development and thus improving the quality of life in society.

After a short discussion of quality of life concept and an overview of theoretical literature and empirical findings on its components, the paper describes the multiple-criteria decision analysis (MCDA) method as a methodological tool to assess which production sectors can contribute most to enhancing quality of life. Next, the paper determines the quality of life criteria and selects multi-functional sectors that are promising in terms of achieving higher quality of life. This is followed by the description of the procedures for production sector assessment and the presentation of results. Key findings for policy making are presented in the conclusion.

\section{QUALITY OF LIFE AND ITS COMPONENTS}

\section{Quality of life is understood as a relatively broad concept,}

which includes elements that generate happiness and life satisfaction at the individual level. These are also aggregated, incorporating interaction and synergy between them, and supplemented with new elements that only occur at a higher, common level (e.g. the role of the state, political system and similar), and relate to society as a whole. Happiness and life satisfaction are individual/subjective categories, while quality of life is an aggregate, social/objective category and is as such more appropriate for the analysis. In other words, individuals are more or less happy or satisfied with their life, which is their subjective assessment, while the society as a whole objectively delivers a certain level of the quality of life.

Quality of life, which is the overall objective of this work, can be broken down into components, the broadest of which are known as domains. One finds various domains defined in the literature. The European Quality of Life Survey (EQLS) 
DRUŠ. ISTRAŽ. ZAGREB BR. 2 (112),

STR. 337-357

SLABE ERKER, R. LAVRAČ, $V$.: THE APPLICATION OF. GOD. 20 (2011)

(Boehnke, 2005) distinguishes between the following determinants of subjective well-being: access to material resources (having), social relationships and social support (loving), perceptions of society (being) and use of time and life-work balance (time pressure). Others assess life satisfaction using the following domains: education, employment, material standard of living, housing, health and social life. In a report for the Balaton Group, Bossel (1999) used seven basic 'orientors' to define a system of sustainable indicators: existence, effectiveness, freedom of action, security, adaptability, co-existence, psychological needs. Layard (2006) defines seven factors with the greatest influence on happiness: family relationships, financial situation, work, community and friends, health, personal freedom and personal values. Frey and Stutzer (2002) divide factors influencing happiness into three groups: economic expectations (prosperity, recession), personality factors (temperament, personal characteristics and cognitive disposition) and socio-demographic factors (age, gender, nationality, health, intelligence and education, interpersonal relationships, religion). Hayo (2007) assesses the effects of transition on life satisfaction in the countries of Central and Eastern Europe. The model uses variables demonstrated to be significant in influencing life satisfaction in international research works covering developed countries. These variables can be combined in the following domains: individual level variables (age, gender, status), socio-demographic variables (state, education, religious affiliation, size of community) and economic variables (form of employment, income). The importance of various economic variables for subjective economic well-being are studied by Verbic and Stanovnik (2006). They find out that subjective economic well-being is highly influenced by actual household income, household size, household composition, and household assets. Headey et al. (1985) have four groups of variables in their well-being models: social background, personality, social support networks and satisfaction with individual domains of life. Garcia et al. (2007) created a happiness index including three broader groups of variables (in-dices): an economic index, health index and personal value index (respect, fairness, honesty, etc.).

The overview of theoretical and empirical research on the main quality of life domains will serve later in the part Quality of life criteria in alternative scenarios as a basis for the determination of these criteria, but first the methodology used has to be explained in detail.

\section{METHODOLOGY FOR MULTI-CRITERIA DECISION ANALYSIS}

Multiple-criteria decision analysis (MCDA) method was developed for complex decision-making in cases where a selection must be made from multiple alternatives, such as poli- 
DRUŠ. ISTRAŽ. ZAGREB GOD. 20 (2011), BR. 2 (112)

STR. $337-357$

SLABE ERKER, R., LAVRAČ, V.: THE APPLICATION OF.. multiple criteria. The criteria may be independent and unrelated, conflicting, i.e. competitive or complementary, or - as will be the case here - partial sub-objectives of an overall objective being pursued.

The methodological approach of the MCDA and its well-developed, dynamic, interactive programming tools ensure consistent decision-making in conditions of multiple alternatives subject to multiple criteria, since the method enables comparisons of alternative solutions and their ranking or prioritisation. As a multiple criteria methodology, MCDA is used particularly for complex decision-making problems, such as choices between various scenarios, technological options or policy instruments in the field of energy and the environment (see Beinat et al., 1994 and Diakoulaki et al., 2005). It is particularly useful when addressing a large selection of possible alternative solutions and when a large number of criteria must be taken into account. Up to 15 criteria or objectives can reasonably be included in a MCDA procedure. A greater number of criteria would make it more difficult to make comparisons and determine differences in their relative significance. The advantage of this method lies in the fact that it supports the structuring and formalisation of the entire decision-making process and the active role of decision-makers, who may define the decision-making process parameters in all phases according to their preferences, primarily via ranking and weighting of criteria.

By evaluating individual alternatives from the position of multiple criteria, this method allows the contribution of individual alternatives to achieving the overall objective to be determined, and therefore to define the alternatives that contribute most to achieving the overall objective. In other words, the MCDA methodological framework, with its dynamic and interactive approach produces solutions that best match the preferences of decision-makers. The assessment of alternative solutions by individual criteria is carried out by decision-makers or an expert group, which must reach a consensus among themselves, frequently on the basis of compromise solutions. In the last instance, experts have to speak with one voice. The advantage of the expert group is precisely in the fact that the assessment is more objective. This means that individual subjective assessments, particularly extreme ones, rule themselves out by averaging.

There are two versions of the MCDA method for multiple criteria ranking of discrete alternatives: the MAVT (Multi-Attribute Value Theory) method and the 'outranking' method. The latter defines indices of preferences between pairs of alternatives, which leads to a final ranking of all alternatives (Lootsma, 1999). The advantage of the MAVT method is that 
DRUŠ. ISTRAŽ. ZAGREB GOD. 20 (2011), BR. $2(112)$

STR. 337-357

SLABE ERKER, R., LAVRAČ, V.: THE APPLICATION OF. it is simpler, more transparent, more comprehensible for all participants in the decision-making process within the workshop, and is therefore more useful. Furthermore, this version is compatible with cost-benefit analysis, since both costs and benefits are based on utility principles, and since decisions arise from explicit or implicit weighting between conflicting interests or aspects (Diakoulaki et al., 2006). For the purposes of this research, the MAVT version was selected. For simplicity, the paper makes reference to the MCDA method, although its MAVT version was actually used.

The essence of the MCDA method is that a total value is calculated in the final phase for each alternative as a single number, representing its total power, contribution, or importance in achieving the overall objective, taking into account all selected criteria and their relative importance as expressed by decision-makers' preferences. The starting point of the MAVT model is the definition of partial value functions across individual criteria for each alternative, according to its contribution or performance, in the range 0 to 100 . Stated in more detail, these partial value functions are calculated as the relative deviation from the best performance of a single criterion achieved by any alternative i.e. from a maximum (or a minimum) result. This means that the maximum performance is assigned a partial value of 100 and the minimum a value of 0 , with intermediate results given an intermediate partial value dependent on their relative divergence from one or the other extreme value. The value functions differ according to the risk attitude of participants in the experiment.

The basic characteristic of partial value functions is that alternative $a$ has a clear advantage over alternative $b$, if $v_{i}(a)>v_{i}(b)$. The calculation of partial values differs according to the desired direction of performance for each criterion i.e. whether to maximise a criterion (e.g. profit) or minimise it (e.g. costs). Since in this case the aim is to maximise all criteria, the description of the methodology is restricted to this case only. When the intention is to maximise the criterion value, the partial value $v_{i}$ of alternative $a$ is:

$$
v_{i}(a)=\frac{g_{i}(a)-g_{i}(\min )}{v_{i}(\max )-g_{i}(\min )}
$$

where

$g_{i}(a)$ is the performance of each alternative (sector) $a$ to criterion $i$

$g_{i}(\min )$ is the minimum performance to criterion $i$ $g_{i}(\max )$ is the maximum performance to criterion $i$ 
DRUŠ. ISTRAŽ. ZAGREB GOD. 20 (2011), BR. 2 (112)

STR. $337-357$

SLABE ERKER, R., LAVRAČ, V.: THE APPLICATION OF..
It must also be noted that, based on certain assumptions, when the performance of an individual criterion does not cover the available scale in full, the partial values are simply calculated as the percentage of the best result. In that case, this simplified formula is used:

$$
v_{i}(a)=\frac{g_{i}(a)}{g_{i}(\max )}
$$

Partial values are then aggregated for each alternative across all criteria to produce a total value for each alternative. This then serves as the basis for ranking the alternatives (sectors) according to their contribution to all criteria together i.e. to the overall objective. The transformation from partial to total value functions implies the use of an aggregation formula that includes the weights of individual criteria, which decision-makers have allocated to them in advance. The simplest aggregation method is additive:

$$
V(a)=\sum_{i} w_{i} \bullet v_{i}(a)
$$

where $V(a)$ is the total value of each alternative $a$ and $w_{i}$ is the weight of individual criterion $i$. The alternatives are then ranked by $V(a)$ from the highest to the lowest value.

Several weighting models have been developed within an MCDA framework. It is reasonable to restrict the selection to methods that make it easier for decision-makers to comprehend their own preferences, in order to avoid complications and inconsistencies that would be difficult to resolve in a workshop. In this case, two weighting methods were used in parallel, which, in line with the literature in this field, allows participants to articulate their preferences in an iterative manner, and to confirm or correct initially selected weights. The RATIO method and the LEVEL method were therefore included in the MCDA procedure.

In the RATIO weighting method, criteria were ranked from the most to the least significant, and then numerically assessed according to the assumed difference in their relative significance. In practical terms, this means that the most significant criterion is allocated a value $a=100$, and then the decision-maker defined value $b \leq 100$ for the next ranking, relatively less significant, criterion. The nearer value $b$ is to 100 , the smaller the difference in the relative significance of the two criteria. The decision-maker then allocates value $c \leq b$ to the third-ranking criterion, and so on until the lowest-ranking criterion. The values allocated in this manner are then transformed into relative weights by standardisation (total $=1$ or $100 \%$ ). 
DRUŠ. ISTRAŽ. ZAGREB GOD. 20 (2011), BR. 2 (112)

STR. 337-357

SLABE ERKER, R. LAVRAČ, V.: THE APPLICATION OF.
The LEVEL weighting method uses a hierarchical scale, where the decision-maker has the opportunity to place each criterion according to its relative significance. Of course, the criteria are ranked beforehand. This method does not require preferences to be indicated or defined with a numerical ranking, but only in the qualitative visual form of a column. The most significant criterion is placed in the top row, with less significant criteria being placed in lower rows. Empty rows indicate the size of the difference in significance between successive criteria (more empty rows indicate a greater relative difference). The weighting is obtained by assigning a number to each row, starting with 1 for the lowest row, 2 for the penultimate and so on up to the highest row, the serial number of which will equal the total number of rows, since empty rows are also assigned a number. The values allocated in this manner are then transformed into relative weights by standardisation (total $=1$ or $100 \%$ ) (Lootsma, 1999).

If both methods are used in parallel, decision-makers can iteratively advance in the articulation of their preferences, by using the second method to confirm or revise their assessment from using the first method. It should be said in this regard that in principle the final results - prioritised alternatives - are not very sensitive to the selection of weighting method. It is also seen in practice that when both weighting methods are used, the differences in final weightings are small, and therefore negligible in the final results. The research results therefore only disclose results obtained using the RATIO weighting method.

The crucial element of the MCDA method is the assessment of relative performances or contributions of individual alternatives to individual criteria. This is carried out by an expert group, which is familiar with the criteria and the alternative solutions. The rows (alternatives) are separately assessed across individual columns (criteria). In the final phase, a ranking of alternatives from highest to lowest in relation to their total contribution to the overall objective (weighted sum of all criteria) - in this case, higher quality of life - is obtained.

As stated, the MCDA method also permits sensitivity analysis, which can verify the robustness of the results acquired. Two further scenarios will be defined in addition to the Basic Scenario. In order to provide for the comparability of scenarios, it is reasonable to merely change the criteria ranking and hence their weights, without changing the selection of criteria. Furthermore, there is also no substantive basis for changing the assessed performances of individual sectors to fulfilment of individual quality of life criteria in different scenarios. The MCDA method is illustrated schematically in Figure 1. 
DRUŠ. ISTRAŽ. ZAGREB GOD. 20 (2011),

BR. $2(112)$

STR. 337-357

SLABE ERKER, R.,

LAVRAČ, V.:

THE APPLICATION OF..

FIGURE 1

Flowchart of MCDA

method

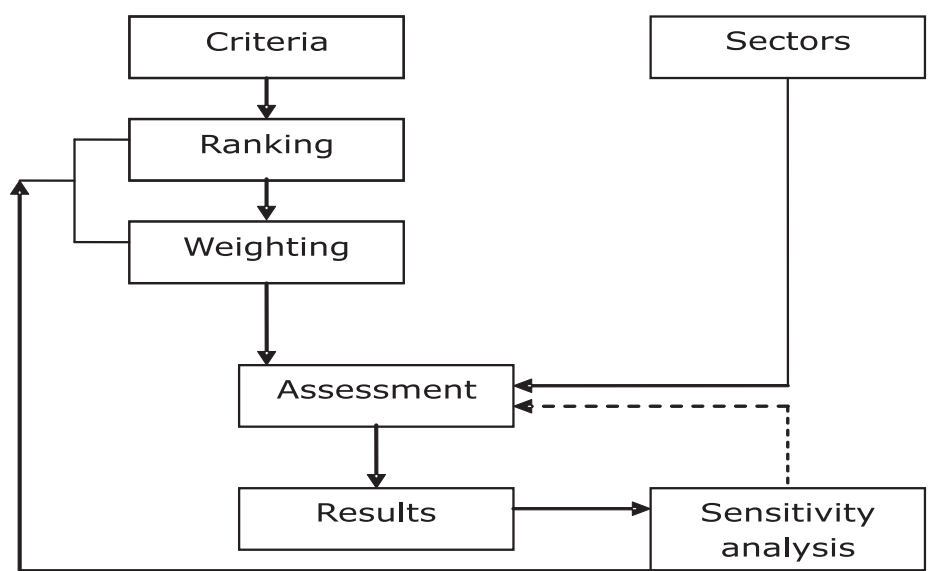

\section{QUALITY OF LIFE CRITERIA IN ALTERNATIVE SCENARIOS}

The literature conventionally groups basic domains of quality of life as economic, social and environmental domains, which directly resembles the main three components of sustainable development, so this link is quite obvious. The modern paradigm of sustainable development as an overarching objective represents the quality of life in the total of its domains - the "basket of quality of life", as we name it. Persisting in a rigid adoption of the three basic domains (economic, social and environmental) of sustainable development as the main determinants of quality of life and treating them in a symmetric and completed manner, we would probably have to deal with too many criteria, which would impair the simplicity and transparency of the approach. We therefore decided pragmatically to limit ourselves to just some selected criteria from within each of the three groups, which have proved the most significant in the literature reviewed briefly in the part Quality of life and its components. These factors were also verified in a broader expert and public debate organised on a web forum (for more, see Slabe Erker and Lavrač, 2009). The criteria chosen are initially stated in a random order to avoid an a priori definition of their relative importance, since the literature differs strongly on which the most significant are. Three different scenarios are elaborated below, differing in terms of the various assumptions on the significance of individual quality-of-life determinants.

The authors selected the following quality of life determinants as criteria, which were used to assess the contribution of individual production sectors to achievement of the overall objective - a higher quality of life: interpersonal relations, material standard of living, employment, health, social security, education and environment. In terms of content, 
DRUŠ. ISTRAŽ. ZAGREB GOD. 20 (2011) BR. $2(112)$

STR. 337-357

SLABE ERKER, R. LAVRAČ, V.:

THE APPLICATION OF.

$\rightarrow$ TABLE

Ranks and weights for individual criteria in the Basic Scenario these quality of life determinants can be broadly divided into three basic social level domains plus an individual level domain. Material standard of living and employment clearly belong to the economic domain, environment to the environmental domain, and interpersonal relationships and social security belong to the social domain, while the other two, health and education are grouped as personal determinants of happiness. The most significant personal determinants of happiness at the individual level include various socio-demographic characteristics of individuals (gender, age), which do not change in the short term and which cannot be directly controlled by economic policy, and are therefore irrelevant for the purposes of this paper.

Various theories and empirical analyses of happiness functions provide very different key quality-of-life determinants. For example, some authors emphasise material standard of living (income and wealth), other focus on health, others on interpersonal relationships. This diversity of views was taken into account by creating alternative scenarios, which allows different ranking of criteria and hence also their different weighting. The aim was therefore to use the analyses to determine precisely whether different views on the importance of individual quality of life determinants significantly influence the identification of production sectors that could contribute most to overall quality of life, or are some other factors more decisive?

In the Basic Scenario, criteria are ranked according to the understanding of quality of life as an objective, broader social category, by placing health first and then material standard of living. In the Slovenian Public Opinion Survey (1999-2004) by the Public Opinion and Mass Communication Research Centre at the Faculty of Social Sciences in Ljubljana, for example, respondents stated that disease is what they fear most, and therefore the main factor in their unhappiness. In this scenario, individual criteria were assigned values or weights, which represent a relative difference between two ranks (Table 1). This weights therefore follows the ranking itself: for consisten$c y$, it is not therefore possible for a lower ranking criteria to have a higher weights.

\begin{tabular}{lcrrr}
\hline & & \multicolumn{3}{c}{ Basic Scenario } \\
\cline { 3 - 5 } Criteria & Code & Rank & Value & Weights \\
\hline Interpersonal relationships & C1 & 6 & 40 & $9 \%$ \\
Material standard of living & C2 & 2 & 90 & $19 \%$ \\
Employment & C3 & 3 & 80 & $17 \%$ \\
Health & C4 & 1 & 100 & $22 \%$ \\
Social security and equality & C5 & 5 & 50 & $11 \%$ \\
Education & C6 & 7 & 30 & $6 \%$ \\
Environment & C7 & 4 & 75 & $16 \%$ \\
\hline
\end{tabular}


DRUŠ. ISTRAŽ. ZAGREB GOD. 20 (2011), BR. $2(112)$

STR. $337-357$

SLABE ERKER, R., LAVRAČ, V.: THE APPLICATION OF..

(1) TABLE 2 Ranks and weights for individual criteria in Scenario 1 and 2
A further two scenarios were designed to analyse the sensitivity of results to changes in the ranking of criteria. In Scenario 1, based on the expert literature, criteria were again ranked according to the concept of quality of life as an objective, broader social category, but this time placing material standard of living first, followed by social security and equality, while in Scenario 2, criteria were ranked according to a concept of quality of life as a subjective, individual category, emphasising its non-material dimensions (interpersonal relationships in society, followed by social security and equality). Individual criteria were again weighted to indicate the relative differences between ranks. The ranking of criteria in Scenarios 1 and 2 and the related weights are given in Table 2 .

\begin{tabular}{|c|c|c|c|c|c|c|c|}
\hline \multirow[b]{2}{*}{ Criteria } & \multirow[b]{2}{*}{ Code } & \multicolumn{3}{|c|}{ Scenario 1} & \multicolumn{3}{|c|}{ Scenario 2} \\
\hline & & Rank & Value & Weights & Rank & Value & Weights \\
\hline Interpersonal relationships & $\mathrm{C} 1$ & 3 & 65 & $16 \%$ & 1 & 100 & $20 \%$ \\
\hline Material standard of living & $\mathrm{C} 2$ & 1 & 100 & $25 \%$ & 4 & 80 & $16 \%$ \\
\hline Employment & $\mathrm{C} 3$ & 6 & 30 & $8 \%$ & 5 & 70 & $14 \%$ \\
\hline Health & C4 & 4 & 60 & $15 \%$ & 3 & 85 & $17 \%$ \\
\hline Social security and equality & C5 & 2 & 80 & $20 \%$ & 2 & 90 & $18 \%$ \\
\hline Education & C6 & 7 & 10 & $3 \%$ & 6 & 50 & $10 \%$ \\
\hline Environment & $\mathrm{C} 7$ & 5 & 50 & $13 \%$ & 7 & 35 & $7 \%$ \\
\hline
\end{tabular}

\section{PROMISING PRODUCTION SECTORS}

\section{FROM THE VIEWPOINT OF INCREASING QUALITY OF LIFE}

The aim is to define the production sectors that can contribute most to the sustainable aspects of social development, and hence of improving quality of life. The final purpose of identifying such sectors is that the state could support their development with appropriate economic initiatives, thereby contributing to increasing the quality of life.

The task of selecting the sectors that could make a significant contribution to overall quality of life was challenging, due to the potential for their overlapping and confusion between criteria and sectors. This is a problem of similarity or excessive overlapping between some sectors and criteria (e.g. healthcare - health, or environmental activities - the environment). In that case, the effect of those sectors on their related criteria would be exceptionally high (almost full), which would distort the predictive power of the methodology and complicate the analysis of results.

Another problem referring to the definition of sectors relates to the selection of the sector classification. The basis could be formal statistical classifications, such as the Statistical Classification of Economic Activities in the EC (NACE), which covers 
DRUŠ. ISTRAŽ. ZAGREB GOD. 20 (2011) BR. 2 (112),

STR. 337-357

SLABE ERKER, R., LAVRAČ, V.:

THE APPLICATION OF. all activities or sectors that together generate GDP. Another possibility would be to replace this organisational and process-based principle with focusing on outputs i.e. goods and services that are directly linked to quality of life. These classifications include the CPA (Statistical Classification of Products by Activity in the EEC) and the $\mathrm{CN}$ (Combined Nomenclature). A third possibility would be to restrict the selection to technologically promising sectors as vehicles of development and within that group to the technological niches that could have particular importance in the future for Slovenian socio-economic development (see Stanovnik, 2008).

The authors decided to select a classification, where sectors are defined by the characteristics of both technological processes and their outputs (goods and services), which are used for the purposes of scientific and technological classifications in high-technology sciences in industry and life sciences. This is an integrated approach that combines elements of the approaches mentioned above, or some form of compromise solution between them. The selection of sectors is based on Techexpo, a scientific and technological classification in the field of industry and life sciences. Most sectoral classifications capture either industrial or science and technology sectors alone, and are mutually exclusive. An advantage attributed to the Techexpo classification is that it is comparable and compatible with the SIC code (Standard Industrial Classification), the DTIC (Defence Technical Information Center), ISBN (International Standard Book Number), LOC (Library of Congress) and other classifications. It focuses on the field of high technology, rather than traditional industries. Since it focuses on technology, it links industrial, scientific and R\&D classifications.

Another issue is the aggregation level. The sectors could be combined in content-related groups and divided into subsectors, which the Techexpo classification allows for, with its 33 basic sectors being broken down into 324 sub-sectors. Here, an intermediate level of aggregation was selected, using the basic 33-sector classification. It was assessed that this intermediate level of aggregation would offer the greatest analytical power i.e. that this definition of sectors would offer the best method of assessing their contribution to quality of life. Too narrowly defined sectors would be difficult to assess, while too broad a definition would lead to scores that would be too general and tend towards the average.

Of a total of 33 sectors, 16 were selected. The idea behind the selection of sectors was not to avoid empirical determination, but to ex ante exclude, in order to simplify the procedure, those sectors, which - by taking into account our knowledge of Slovenian production structure - are not considered 
DRUŠ. ISTRAŽ. ZAGREB GOD. 20 (2011), BR. $2(112)$

STR. $337-357$

SLABE ERKER, R., LAVRAČ, V.:

THE APPLICATION OF.

$\rightarrow$ TABLE 3

Production sectors to be relevant for a small country like Slovenia, such as space research, or oceanographic matters. The sectors selected are given in Table 3.

\begin{tabular}{lr}
\hline Sectors & Code \\
\hline Agriculture & A1 \\
Biotechnology and biomedicine & A2 \\
Chemistry and chemical engineering & A3 \\
Civil engineering & A4 \\
ICT and computer technology & A5 \\
Ecology and environmental technology & A6 \\
Manufacturing technology and automation & A7 \\
Materials & A8 \\
Mechanical and industrial engineering & A9 \\
Photonics & A10 \\
Power and energy conversion technology & A11 \\
Propulsion, engines and fuels & A12 \\
Sensors, measurement and test and laboratory equipment & A13 \\
Software engineering and applications & A14 \\
Sub-assemblies and components & A15 \\
Surface transportation & A16
\end{tabular}

\section{RESULTS OF THE ASSESSMENT OF PRODUCTION SECTOR CONTRIBUTION TO QUALITY OF LIFE}

When the criteria and sectors have been defined, the assessment of individual sector contribution to fulfilling individual criteria and the overall objective - quality of life in Slovenia can begin, based on the selected methodology. These contributions could be presented in a rectangular matrix with 7 selected criteria in the columns, and the 16 selected sectors in the rows.

It would be ideal if this contribution could be measured on the basis of objective criteria in the form of different indicators that could be mechanically applied to individual sectors. The type of indicators measuring various multiplicative, external or synergic effects that would be required is simply not available, except possibly in the economic domain. However, even if such indicators were available, the data would be difficult to break down by sector. It was therefore necessary to make estimates, which by definition are to some extent subjective. This process can be made more objective by entrusting the assessment to an expert group with expertise in the field of quality-of-life determinants, and an understanding of the specific features of the individual industrial sectors and technological processes. In the final phase, the expert group must arrive at a consensus on their assessment of sector-by-sector 
DRUŠ. ISTRAŽ. ZAGREB GOD. 20 (2011) BR. 2 (112),

STR. 337-357

SLABE ERKER, R. LAVRAČ, V.:

THE APPLICATION OF. is based on compromise or, ideally, strength of argument. In order to assess the contribution of individual sectors to the fulfilment of individual criteria (assessment within the matrix), an ad hoc group of experts from the Institute for Economic Research (IER) was formed, which had the requisite knowledge from various, primarily economic sectors: macroeconomics, finance, econometrics, sustainable development, quality of life, happiness economics, environmental economics, technological platforms, science and technology and research and development policy, sectoral specifics, entrepreneurship, innovation policy, marketing, demography and family and social policy.

The expert group first gave assessments of the contribution of individual sectors by column i.e. by individual criteria across all sectors, as required by the MCDA methodology. The reliability of these assessments was verified by the expert group giving a further assessment in another manner, by row i.e. by all criteria for each individual sector. Harmonisation took place wherever these checks indicated considerable divergences between the two assessments. The assessments of individual sector contributions were found to be the most significant single influence of model parameters on the final results of the analysis.

The previous sections provided the description of the methodology used, a detailed explanation of the selection of criteria and sectors, and the procedure to assess the individual sector contributions in Slovenia. Here a few words should be added on the criteria ranking itself, and the weighting, carried out during the procedure itself. The ranking of criteria in various scenarios was carried out starting from the findings of expert literature and research reviewed in the field of happiness and quality of life. The weighting of the criteria in the various scenarios necessarily followed their ranking. To ensure consistency, a lower ranking criterion could not have a higher weighting. The actual weighting of individual criteria was within the limits given by their ranks. The RATIO model was used to weight individual criteria, rather than the LEVEL model, which is also allowed within the MCDA method. The LEVEL method was also tested and relevant calculations were made, but these are not presented separately, since the selection of the weighting method only has minimal effects on the overall result, and presenting the results of both methods would only impair transparency.

The calculation of Basic Scenario results was followed by sensitivity analysis, which entailed additional two scenarios. The selection of criteria in these additional two scenarios remained unchanged, only their ranks were adjusted due to different emphasis given to individual criteria in alternative 
DRUŠ. ISTRAŽ. ZAGREB GOD. 20 (2011), BR. $2(112)$

STR. $337-357$

SLABE ERKER, R., LAVRAČ, V.:

THE APPLICATION OF..

(1) TABLE 4

Results - Sector

Rankings in Slovenia quality of life literature. The possibility of only changing criteria weighting within the sensitivity analysis, leaving criteria rankings unchanged, was tested but rejected, since changing only the weights had a minimal effect on the final results.

The overall value for an individual sector does not reveal much on its own. The calculation technique used scores from 1 to 5 , in which a sector achieved the highest total value of 1 $(100 \%)$ if it received a maximum score for each criterion. Furthermore, a high total value e.g. near or over $80 \%$ represents an absolute measure of the strength of that sector in achieving the overall objective.

Each sector was also assigned an average ranking, based on its average total value for all three scenarios. This means, if one assumes that all three scenarios are of an equivalent value, that an 'overall winner' can be selected, with other sectors ranked behind it. The key results are presented in Table 4 and in Figure 2.

\begin{tabular}{|c|c|c|c|c|c|c|c|c|c|c|c|}
\hline \multirow[b]{2}{*}{ Sector } & \multicolumn{2}{|c|}{ Basic Scenario } & \multicolumn{3}{|c|}{ Scenario 1} & \multicolumn{3}{|c|}{ Scenario 2} & \multicolumn{3}{|c|}{ Scenario Average } \\
\hline & $\begin{array}{l}\text { Total } \\
\text { Value }\end{array}$ & Rank & Sector & $\begin{array}{l}\text { Total } \\
\text { Value }\end{array}$ & Rank & Sector & $\begin{array}{l}\text { Total } \\
\text { Value }\end{array}$ & Rank & Sector & $\begin{array}{r}\text { verage } \\
\text { Total } \\
\text { Value }\end{array}$ & $\begin{array}{l}\text { Average } \\
\text { Ranking }\end{array}$ \\
\hline A11 & 0.83 & 1 & A11 & 0.79 & 1 & A5 & 0.78 & 1 & A11 & 0.80 & 1 \\
\hline A6 & 0.74 & 2 & A5 & 0.75 & 2 & A11 & 0.78 & 2 & A6 & 0.73 & 2 \\
\hline A5 & 0.66 & 3 & A6 & 0.75 & 3 & A6 & 0.71 & 3 & A5 & 0.73 & 3 \\
\hline A14 & 0.63 & 4 & A14 & 0.64 & 4 & A14 & 0.66 & 4 & A14 & 0.64 & 4 \\
\hline A4 & 0.57 & 5 & A4 & 0.61 & 5 & A4 & 0.57 & 5 & A4 & 0.58 & 5 \\
\hline A13 & 0.52 & 6 & A16 & 0.53 & 6 & A16 & 0.51 & 6 & A16 & 0.51 & 6 \\
\hline $\mathrm{A} 2$ & 0.52 & 7 & A13 & 0.46 & 7 & A10 & 0.51 & 7 & A13 & 0.48 & 7 \\
\hline A16 & 0.50 & 8 & A10 & 0.46 & 8 & A13 & 0.46 & 8 & A2 & 0.47 & 8 \\
\hline A10 & 0.43 & 9 & A2 & 0.45 & 9 & A2 & 0.45 & 9 & A10 & 0.46 & 9 \\
\hline A8 & 0.42 & 10 & A8 & 0.38 & 10 & A8 & 0.34 & 10 & A8 & 0.38 & 10 \\
\hline A12 & 0.40 & 11 & A12 & 0.35 & 11 & A7 & 0.32 & 11 & A12 & 0.35 & 11 \\
\hline A7 & 0.33 & 12 & A7 & 0.33 & 12 & A12 & 0.30 & 12 & A7 & 0.33 & 12 \\
\hline A3 & 0.32 & 13 & A9 & 0.31 & 13 & A9 & 0.29 & 13 & A9 & 0.30 & 13 \\
\hline A15 & 0.31 & 14 & A3 & 0.26 & 14 & A3 & 0.27 & 14 & A3 & 0.28 & 14 \\
\hline A9 & 0.30 & 15 & A15 & 0.23 & 15 & A15 & 0.25 & 15 & A15 & 0.26 & 15 \\
\hline A1 & 0.22 & 16 & A1 & 0.20 & 16 & A1 & 0.19 & 16 & A1 & 0.20 & 16 \\
\hline
\end{tabular}

In the Basic Scenario (Sc-os), the following five sectors ranked highest: power and energy conversion technology (A11), ecology and environmental technology (A6), ICT and computer technology (A5), software engineering and applications (A14), and civil engineering (A4). In Scenario 1, the same 5 sectors ranked highest, the only difference being that ICT and computer technology (A5) and ecology and environmental technology (A6) swapped places in the ranking. Scenario 2 is similar. The same five sectors appear, with three sectors in different places compared to the Basic Scenario (A11, A6 and A5), or just two compared to Scenario 1 (A11 and A5). 


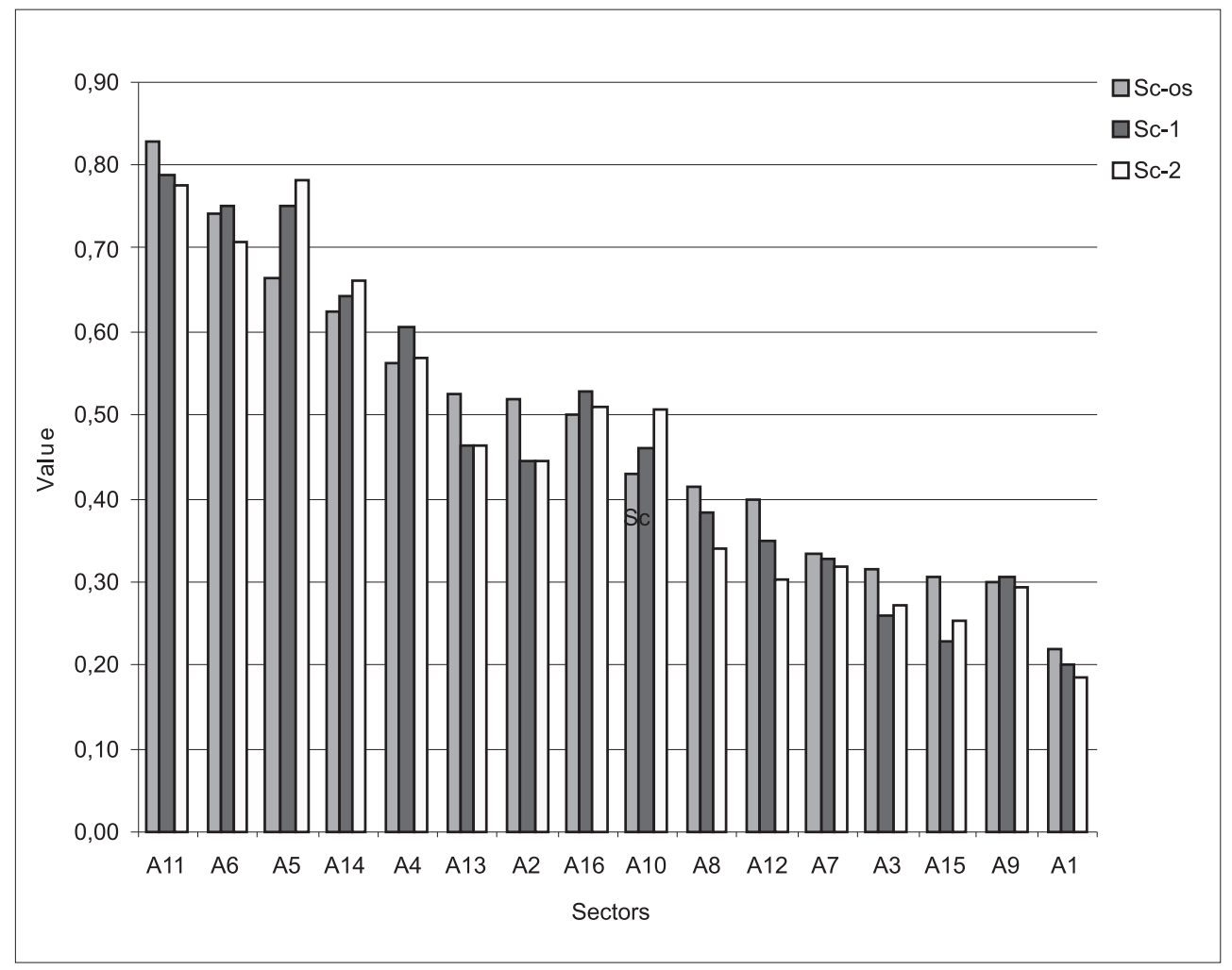

i FIGURE 2

Results - Sector Rankings in Slovenia
In the Basic Scenario, the five lowest-ranking sectors were as follows: agriculture (A1), mechanical and industrial engineering (A9), sub-assemblies and components (A15), chemistry and chemical engineering (A3), and manufacturing technology and automation (A7). In Scenario 1, the same five sectors rank at the bottom, but three are placed differently (A9, A3 and A15) compared with the Basic Scenario. The five lowest-ranking sectors in Scenario 2 differed to those in the Basic Scenario, and included propulsion, engines and fuels (A12), while sector A7 was not part of this group. Three sectors (A9, A15 and A3) were placed differently compared with the Basic Scenario. Compared to Scenario 1, Scenario 2 again had one different sector (A12), which replaced sector A7; the remaining four sectors had the same placings in the final five.

The three scenarios enable the definition of an overall result and the definition of an 'average' scenario. The final overall top-ranking sectors in Slovenia are: power and energy conversion technology (A11), ecology and environmental technology (A6), ICT and computer technology (A5), software engineering and applications (A14), and civil engineering (A4). The top-ranking sectors are in the same order as in the Basic Scenario. 
DRUŠ. ISTRAŽ. ZAGREB GOD. 20 (2011), BR. $2(112)$

STR. $337-357$

SLABE ERKER, R., LAVRAČ, V.: THE APPLICATION OF.
The following findings can be drawn from the results: (i) First, the results were quite as expected. The sectors that were anticipated to score highly indeed occupied the higher positions on the scale, and vice versa. (ii) Second, the sensitivity analysis indicated that the alternative scenarios did not significantly change the results compared to the Basic Scenario. The sector order did not change significantly, with a few sectors being found a couple of places higher or lower. (iii) Third, as stated above, merely changing the weights for the same individual criteria rankings, or changing the weighting method (RATIO method or LEVEL method), had only a negligible influence on the final results (the ranking of individual sectors). (iv) Fourth, most significant for the final results would be the changes in assessments of individual sector contributions to fulfilment of individual criteria; however, as stated, this could not be the subject of sensitivity analysis for reasons of content.

It can be concluded that the sensitivity analysis supported by the additional two scenarios indicated that the results obtained were robust. A second conclusion is that it is not essential exactly which areas of literature on happiness and quality of life are favoured in the selection of criteria (quality-of-life determinants), since the alternative scenarios did not demonstrate a significant impact on final results.

\section{CONCLUSION}

The paper has described a methodology for identifying the production sectors that could make the largest contribution to increasing quality-of-life. This allows policy-makers to support relevant sectors when defining priority areas for structural reform and to adopt initiatives within a range of different economic and other policies - if, of course, there is a consensus on the need to focus more attention in the coming period on increasing quality of life, instead of pursuing one-sided economic growth at any cost. Not only macroeconomic, but also welfare aspects of the proposed development scenarios have to be in the focus (Majcen et al., 2009). It is desirable that these initiatives might be incorporated not only into measures of economic policy (various taxes and subsidies), and social and environmental policy, but also in the broader framework of developing a knowledge society i.e. in various measures in the fields of science and technology, research and development, educational policy, etc.

The proposed method for assessing the contribution of production sectors to quality of life may significantly contribute to the effectiveness of the decision-making process for policymakers and to the quality of institutions and improvement of regulation (Klun \& Slabe Erker, 2009). Although the me- 
DRUŠ. ISTRAŽ. ZAGREB GOD. 20 (2011) BR. $2(112)$

STR. 337-357

SLABE ERKER, R., LAVRAC , V.: THE APPLICATION OF.

thod is ultimately based on subjective assessments and is therefore subject to the risk of potential biases, it is definitely useful for the definition of basic guidelines for policy-makers when choosing among alternative solutions. The results, as indicated by the sensitivity analysis, are quite robust, which is an important indicator of their quality. A range of conceptual and methodological problems were faced during the assessment procedure, which had to be resolved as they arose. This is the first attempt of its kind in Slovenia, and therefore represents in some manner a pioneering work, a logical and methodological experiment, which deserves to be enhanced in further research. The areas for improvement are largely to be found in the need to replace as many soft and subjective choices and decisions as possible with harder and more objective elements. The selection, ranking and weighting of criteria (i.e. quality of life determinants) rather that being based on mutually divergent proposals from the expert literature, should be soundly based on the results of own research in the form of a large-scale survey that would provide more objective initial assumptions. The potential for enhancement within the selection of sectors and the assessment of their contribution to individual quality-of-life determinants lies primarily in the direction of expansion, greater specialisation, and additional training for the expert group. The research work would gain additional value if, in future, the procedure was carried out on an international level, which would also enable comparison of results between countries.

\section{REFERENCES}

Bartolini, S. (2007), Why are People So Unhappy? Why Do They Strive So Hard for Money? Competing Explanations of the Broken Promises of Economic Growth. In: L. Bruni and P. L. Porta (eds.), Handbook on the Economics of Happiness, Cheltenham, Edward Elgar.

Beinat, E., Nijkamp, P. and Rietveld, P. (1994), Value Functions for Environmental Pollutants: A Technique for Enhancing the Assessment of Expert Judgements. Environmental Monitoring and Assessment, 30 (1): 9-23. doi:10.1007/BF00546197

Boehnke, P. (2005), First European Quality of Life Survey: Life Satisfaction, Happiness and Sense of Belonging, Luxembourg: Office for Official Publications of the European Communities.

Bossel, H. (1999), A Report to the Balaton Group. Indicators for Sustainable Development: Theory, Method, Applications, Winnipeg: IISD.

CJMMK FDV (1999-2004), Slovenian Public Opinion Survey 2003/1 (Slovensko javno mnenje 2003/1). http://www.cjm.si/edokumenti

Diakoulaki, D., Henggeler Antunes, C. and Martins, A. G. (2005), MCDA and Energy Planning. In: J. Figueira, S. Greco and M. Ehrgott (eds.), Multiple Criteria Decision Analysis. State of the Art Surveys (pp. 859-890), New York, Springer. doi:10.1007/0-387-23081-5_21 
DRUŠ. ISTRAŽ. ZAGREB GOD. 20 (2011), BR. 2 (112)

STR. 337-357

SLABE ERKER, R., LAVRAČ, V.: THE APPLICATION OF.
Diakoulaki, D., Tourkolias, C., Hohmeyer, O., Bokenkamp, G., Nijs, W. and de Richard, B. (2006), CASES project. Report (1) on Policy Instruments Assessment Methods and Comparative Analysis. Athens, NTUA, UFLENS, VITO, University of Bath.

Frank, H. R. (1999), Luxury Fever, New Jersey: Free Press.

Frey, B. S. and Stutzer, A. (2002), Happiness and Economics (How the Economy and Institutions Affect Well-Being), Princeton and Oxford: Princeton University Press.

Garcia, J., Fuentes, N. C., Borrego, S. A., Gutierrez, M. D. and Tapia, A. (2007), Values and Happiness in Mexico: The Case of the Metropolitan City of Monterrey. In: L. Bruni and P. L. Porta (eds.), Handbook on the Economics of Happiness (pp. 407-428). Cheltenham, Edward Elgar.

Hayo, B. (2007), Happiness in Transition: An Empirical Study on Eastern Europe. Economic Systems, 31 (2): 204-221. doi:10.1016/j.ecosys. 2006.08.003

Headey, B., Holmstrom, E. and Wearing, A. (1985), Models of Well-Being and Ill-Being. Social Indicators Research, 17 (3): 211-234. doi:10. 1007/BF00319311

Klun, M. and Slabe Erker, R. (2009), Business Views of the Quality of Tax, Environment and Employment Regulation and Institutions: The Slovenian Case. International Review of Administrative Sciences, 75 (3): 529-548. doi:10.1177/0020852309337688

Layard, R. (2006), Happiness and Public Policy: A Challenge to the Profession. The Economist Journal, 116 (510): C24-C33. doi:10.1111/j.14680297.2006.01073.x

Lootsma, F. A. (1999), Multi-Criteria Decision Analysis via Ratio and Difference Judgement (Applied Optimization), Dordrecht: Springer.

Majcen, B., Verbic, M., Bayar, A. and Cok, M. (2009), The Income Tax Reform in Slovenia: Should the Flat Tax Have Prevailed? Eastern European Economics, 47 (5): 5-24.

Slabe Erker, R. and Lavrač, V. (2009), Povečanje kvalitete življenja v Sloveniji. Možnosti za uveljavitev alternativnega koncepta družbenega razvoja. Ljubljana: Inštitut za ekonomska raziskovanja.

Stanovnik, P. (2008), Tehnoloska predvidevanja in slovenske razvojne prioritete. Ljubljana: IER.

TECHEXPO (1995), Science E Technology Classification Schedule in the $\mathrm{Hi}$-Tech Areas of Engineering $\mathcal{E}$ Life Sciences. http://ww.techexpo.com/ survey/clas-txt.html

Verbic, M. and Stanovnik, T. (2006), Analysis of Subjective Economic Well-Being in Slovenia. Eastern European Economics, 44 (2): 60-70. 
DRUŠ. ISTRAŽ. ZAGREB GOD. 20 (2011)

STR. 337-357

SLABE ERKER, R., LAVRAČ, $\mathrm{V}$ :

THE APPLICATION OF.

\section{Primjena višekriterijskih procjena proizvodnih sektora na povećanje kvalitete života}

\author{
Renata SLABE ERKER, Vlado LAVRAČ \\ Institut za ekonomska istraživanja, Ljubljana
}

Zamke iskrivljenih uzoraka potrošnje sve više dolaze do izražaja u modernom društvu. Vidimo ih u začaranom krugu preopterećenosti poslom, zaradom i trošenjem, što u pravilu ljudima ne donosi veće životno zadovoljstvo. Istraživanja pokazuju da dolazi do "paradoksa sreće". Barem u razvijenim zemljama, ljudi ne postaju sretniij zbog toga što im se s vremenom stalno povećava materijalno bogatstvo ili životni standard. Ta nas činjenica upućuje na zaključak kako su za zadovoljstvo životom ostali nematerijalni fakłori dobrobiti u najmanju ruku jednako važni kao i materijalni. Zaključujemo i to da paradigma društvenoga razvoja mora biti preusmierena od sve većega jednostranog ekonomskog razvoja pošto-poto prema održivom razvoju, ako ne čak i prema postizanju najveće moguće opće razine sreće u društvu. Ovaj rad donosi originalan pristup pitanju koje promjene u strukturi produkcije, osim promjena uzoraka potrošnje, mogu pridonijeti ostvarivanju veće kvalitete života. Služimo se provjerenom metodom - MCDA (višekriterijska analiza odlučivanja) - kako bismo kombinirali teoretsku i empirijisku literaturu o sreći, s ciljem povećanja kvalitete života i promicanja održivog razvoja. Primjenom metode procjene, uz MCDA, rangiraju se sektori proizvodnje na temelju nïhova doprinosa pojedinačnim kriteriijima i općoj kvaliteti života. Rad se temelji na slovenskim iskustvima, a metoda bi se jednako uspiešno mogla primijeniti i na druge zemlie.

Ključne riječi: zadovoljstvo životom, kvaliteta života, proizvodni sektori, rangiranje, višekriterijska analiza odlučivanja

\section{Multiple Kriterien bei der Bewertung von Produktionsbereichen und ihres Einflusses auf das Wachstum der Lebensqualität}

Renata SLABE ERKER, Vlado LAVRAČ

Institut für Wirtschaftsforschung, Ljubliana

In der modernen Gesellschaft kommen deformierte Konsumverhaltensmuster immer stärker zum Ausdruck. Sie manifestieren sich in dem Teufelskreislauf von

Arbeitsüberbelastung, häufig hohem Verdienst und zu hohen Ausgaben, was die Menschen in der Regel aber nicht 
DRUŠ. ISTRAŽ. ZAGREB GOD. 20 (2011),

BR. $2(112)$

STR. $337-357$

SLABE ERKER, R., LAVRAČ, V.:

THE APPLICATION OF. entsprechendes "Glücksparadox" aufmerksam gemacht: Zumindest in den Industriestaaten werden die Menschen trotz wachsenden Reichtums und höheren Lebensstandards nicht glücklicher. Daraus lässt sich schließen, dass andere, nichtmaterielle Faktoren menschlichen Wohlergehens mindestens ebenso wichtig sind wie materielle Faktoren. Ebenso muss das Paradigma der gesellschaftlichen Entwicklung umgeleitet werden von einseitigem Wirtschaftswachstum um jeden Preis hin zu Nachhaltigkeit, wenn nicht gar zu größtmöglichem Glück innerhalb der Gesellschaft. Dieser Artikel bringt einen originellen Ansatz zur Frage, welche Veränderungen in der Produktionsstruktur - neben Veränderungen im

Konsumverhaltensmuster - zu einer besseren Lebensqualität beitragen können. Unter Anwendung der bewährten MCDAMethode (Multiple Criteria Decision Analysis) kombinieren die Verfasser theoretische und empirische Werke zur Glücksforschung mit dem Ziel, die Lebensqualität zu steigern und das Konzept der Nachhaltigkeit voranzubringen. Die verschiedenen Produktionsbereiche werden rangiert je nachdem, wie sie einzelne Qualitätskriterien erfüllen und allgemein zur Lebensqualität beitragen. Der vorliegende Artikel gründet sich auf eine in Slowenien durchgeführte Untersuchung, könnte aber ohne Weiteres auch auf andere Länder angewandt werden.

Schlüsselbegriffe: Erfülltes Leben, Lebensqualität, Produktionsbereiche, Rangliste, Analyse mit multiplen Kriterien 